\title{
Hydrocephalus, rickets, and the bust of an infant from Renaissance Italy
}

\author{
Jeanette Kohl ${ }^{1,2}$ (D) \\ Received: 15 March 2019 / Accepted: 20 March 2019 / Published online: 18 May 2019 \\ (C) Springer-Verlag GmbH Germany, part of Springer Nature 2019
}

In the depot of the Museo Nazionale di Bargello in Florence is the unusual marble bust of an infant (Fig. 1 and cover). The portrait shows what seems to be a dead boy, with closed eyes in slightly sunken cavities and a pointed nose in the otherwise well-nourished face with its chubby cheeks, folds of fat around the neck, and rounded upper body. He must have been around a year of age when he was portrayed. Usually, portraits draw their power from the sitter's eyes and a varying amount of "staging" by means of clothes and attributes - things that speak to us and tell a story. Yet, this little boy is naked, and there are no signs of his identity or social status.

Infant mortality was high in the fifteenth and sixteenth centuries - and the object is certainly from this period. However, costly marble monuments to children who died at a premature age were not very common in Italy, even in elite social circles. Practically all of the other portrait busts of children from the Renaissance emphasize the liveliness and cheerfulness of their sitters, in particular if they are of a younger age. In a culture dominated by ideas of male lineage, many of these were important portraits carved by stars of the art sceneDonatello, the della Robbia family, Desiderio da Settignano. Male heirs were the future capital of families, and their beauty, virtue, and liveliness were the key ingredients of children's portraits.

Jeanette Kohl

jkohl@ucr.edu

1 Department of the History of Art, University of California, Riverside, 900 University Avenue, Arts Building, Riverside, CA 92521, USA

2 Agnes Gund and Daniel Shapiro Membership, Princeton Institute for Advanced Study, Princeton, NJ, USA
Why then have a bust in costly marble of what looks like a dead child? There have been two attempts at identifying the boy-both see it as a portrait of Filippo di Francesco I. de' Medici by mannerist sculptor Domenico Poggini $[1,2]$. Filippo, the youngest child of Francesco I. de' Medici and Joanna of Austria, died in March 1582 at the age of 4 years and 10 months. As an heir to the throne of Tuscany, he was a central figure in the powerplay between his mother Joanna, daughter of the Holy Roman emperor Ferdinand I., and his father's mistress Bianca Capello who had given birth to an illegitimate son a year before Filippo was born. Filippo died young, probably related to his hydrocephaly. But is this the portrait of a boy of almost five who was known to be weak and who died of hydrocephaly? ${ }^{1}$ Hardly [3].

The interdisciplinary Medici Project and its paleopathological team have investigated the burial place of most children and other members of the Medici family from the sixteenth to the eighteenth centuries, all in their family church of San Lorenzo in the heart of Florence. In 2004, the team opened an ornamental marble slab in the church pavement-and found the entrance to a crypt that contained eight skeletons of Medici children. Among them were the bones of Filippo de' Medici. His skeleton shows a massive vitamin D deficiency, which was responsible for rickets, from which practically all of the Medici children suffered. The paleopathologists explain the phenomenon with hereditary factors such as a diet low in vitamin

\footnotetext{
${ }^{1}$ Even if the portrait was not one of a dead child's and taken earlier in Filippo's life (as Langedijk seems to think), then why the closed eyes in a prestigious marble bust? Sleep, at least to my knowledge, was not a topic in bust portraits of the Italian Renaissance, nor was a child's death. For children's busts, see Kohl [3].
} 


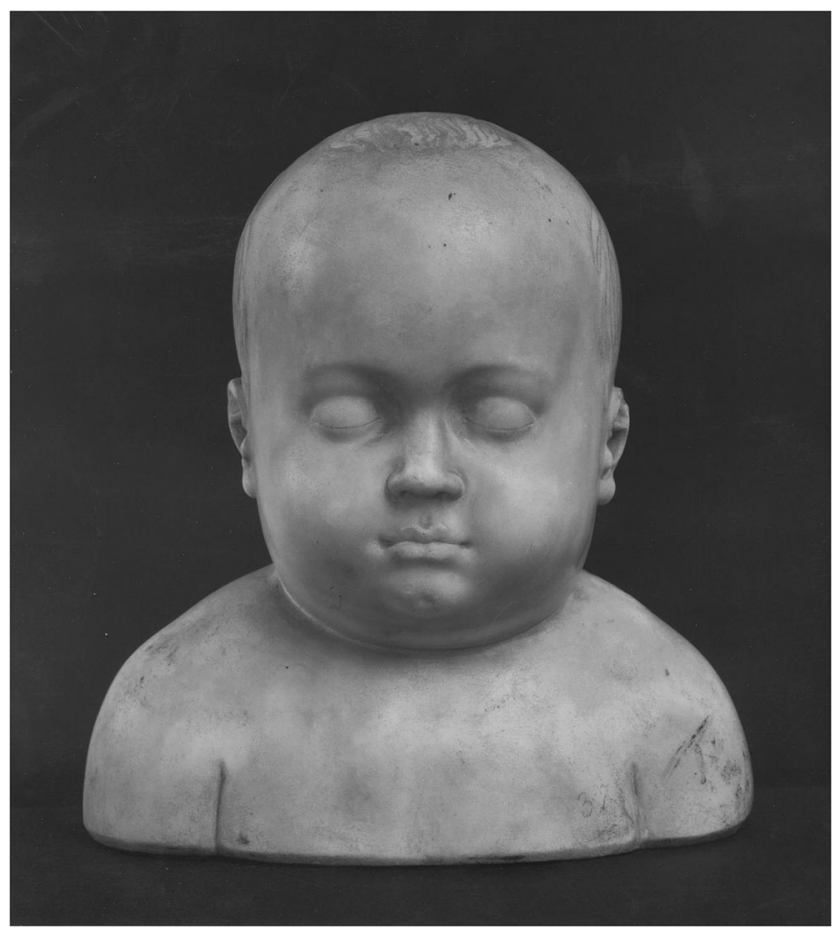

Fig. 1 (cover figure) Marble bust portrait of an infant, the fifteenth or sixteenth century, Museo Nazionale del Bargello, Florence (with permission of the Ministero per i beni e l'attivita culturali-Museo Nazionale del Bargello)

$\mathrm{D}$; the heavy swaddling of babies, as can be seen in the portrait of a baby by the Medici court painter Bronzino from around 1540 (Fig. 2); and the fact that kids from elite families were generally kept inside and protected from sunlight $[4,5]$. After his premature death in 1582, Filippo's skull was opened in a documented autopsy. It shows deep cutting lines (Fig. 3) [6]. The sixteenthcentury autopsy report notes the discovery of what equals a glass of water ("un bicchier d'acqua") in a space between the boy's brain and skull as the likely cause of death $[7,8] .^{2}$

In light of the historical sources and the paleopathological data, it seems rather unlikely that the pretty toddler depicted in the marble bust is Filippo de' Medicinot least because of the significant age difference. But who is this boy who was important enough to be commemorated in a unique marble portrait taken most likely post mortem?

\footnotetext{
2 "A' dì 29 di marzo morse il gran principe di Firenze, Filippo...Seppellissi in S. Lorenzo. Gli stessi medici che lo avevano medicato così fisici come cerusisci, gli segorno la testa, levandone la forma come d'una scodella dove trovorno sotto il primo panno, sopra il cervello, presso a uno bicchier d'acqua; la quale pensorno e credettero tutti conformi che fussi stata la vera causa della morte sua," see Lapini [7]." Il Principe si fece sparare et si trovò il capo pieno d'acqua," in a letter of Grand Duke Francesco to his brother Cardinal Ferdinando de' Medici of April 7, 1589, see the Medici Project results in [8].
}

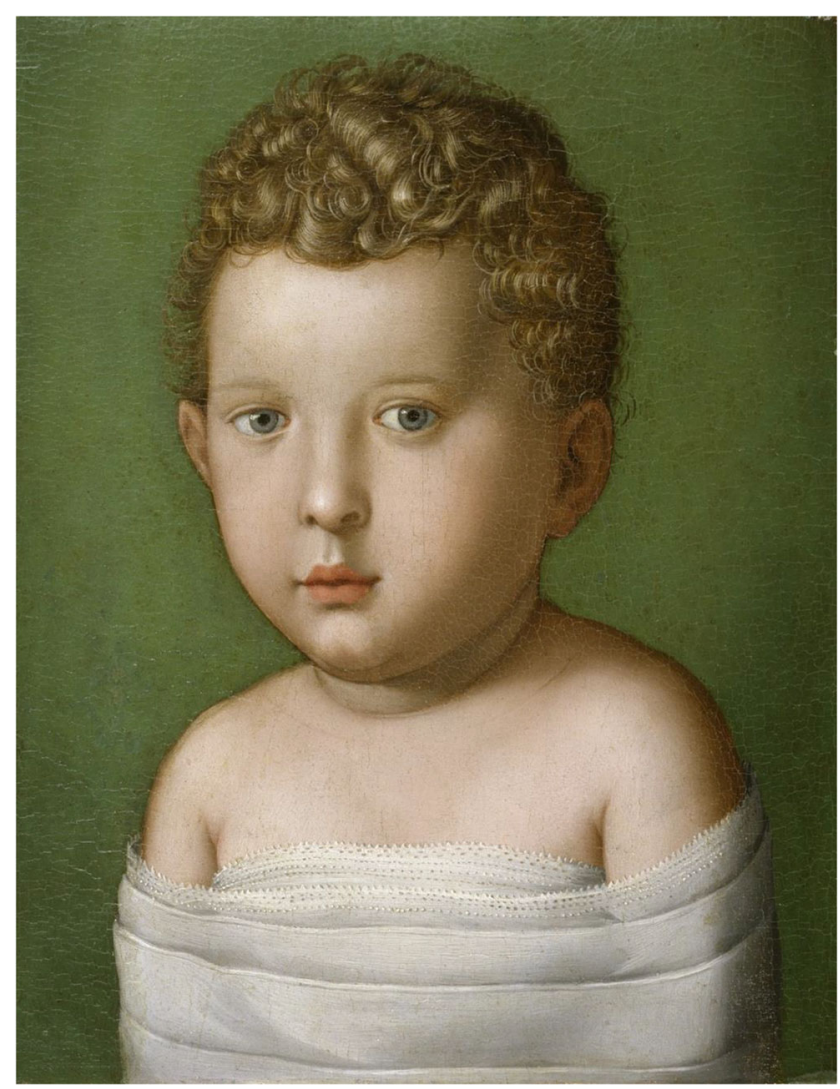

Fig. 2 Agnolo Bronzino, Portrait of a swaddled child, 1540 circa, Walters Art Museum Baltimore (public domain)

The loss of sons who died as infants or were taken from her as adolescents had dashed the spirits of headstrong and robust Eleanor of Toledo, wife of Cosimo I. de' Medici, who was known as "la fecundissima"- the most fertile one. The mother of 11 children died in Pisa on December 17, 1562, only 9 days after her 15 -yearold son Garcia and 4 weeks after her second eldest son, Cardinal Giovanni de' Medici, had both fallen victim to malaria. One particular beloved child of hers was Pedricco, named after her Spanish father Don Pedro Alvarez de Toledo. He had died at the age of only 10 months in June of 1547. The infant is praised as strikingly beautiful and healthy in contemporary letters.

The spouses Cosimo and Eleonora had a strong sense of dynastic family representation, as can be seen from the number of portraits by Bronzino and other court artists. They show the elegant mother together with her beautiful children (Fig. 4), or the sons alone, in a series of eye-catching paintings, such as the one of future Cardinal Giovanni de' Medici as a toddler around the age of 18 months (Fig. 5). I find the family likeness compelling and hence I suggest that the unusual bust in the depot of the Bargello is likely to be a posthumous portrait of Pedricco de' Medici. Pedricco was certainly 

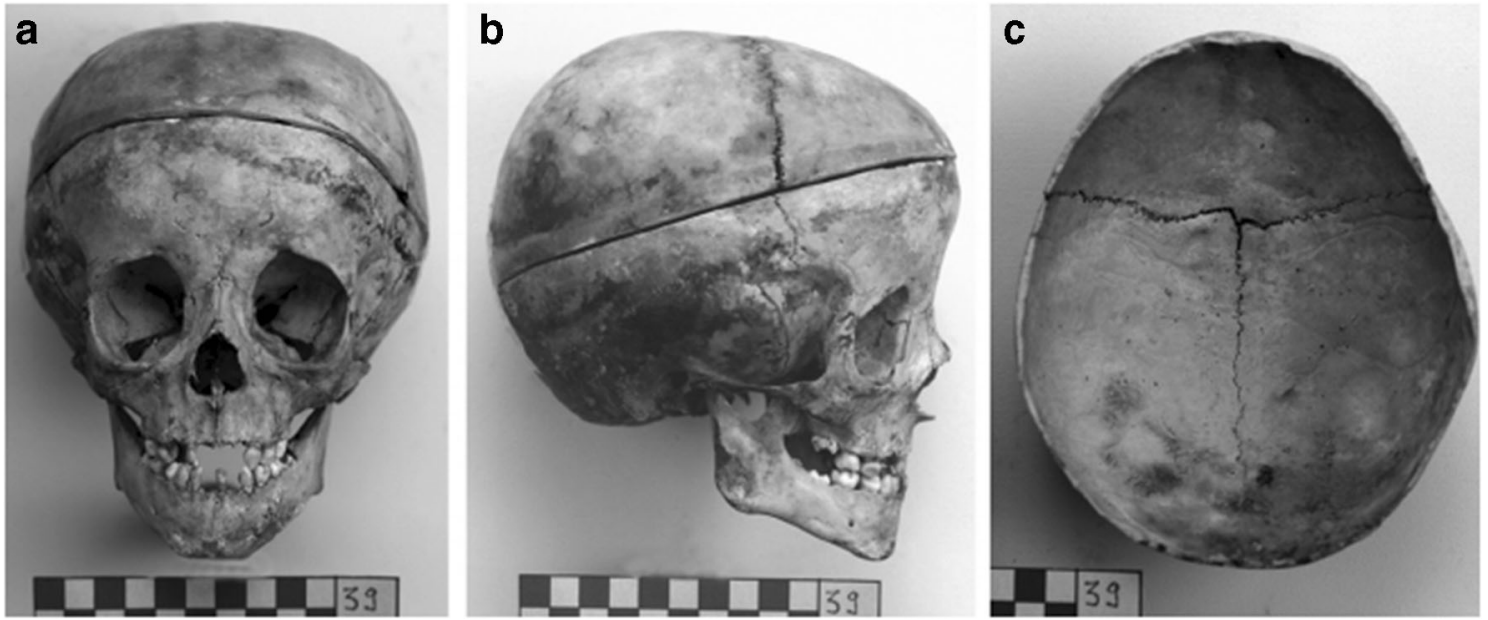

Fig. 3 The skull of Don Filippo de' Medici: anterior view (a); lateral view (b); internal view (c) https://www.researchgate.net/figure/The-skull-of-DonFilippino-anterior-view-a-lateral-view-b-internal-view-c_fig1_277921148. Wiley Online Library (public domain)

important and loved enough to qualify as the baby we see in the Bargello bust. The family likeness with his sibling Don Garcia de' Medici in the Prado is even more striking - Garcia would have been around 2 years when Bronzino portrayed him (Fig. 6).

Their sons were the most important capital of the aspiring new line of Medicis. Neither did they belong to the family branch of Cosimo il Vecchio's descendants nor could they

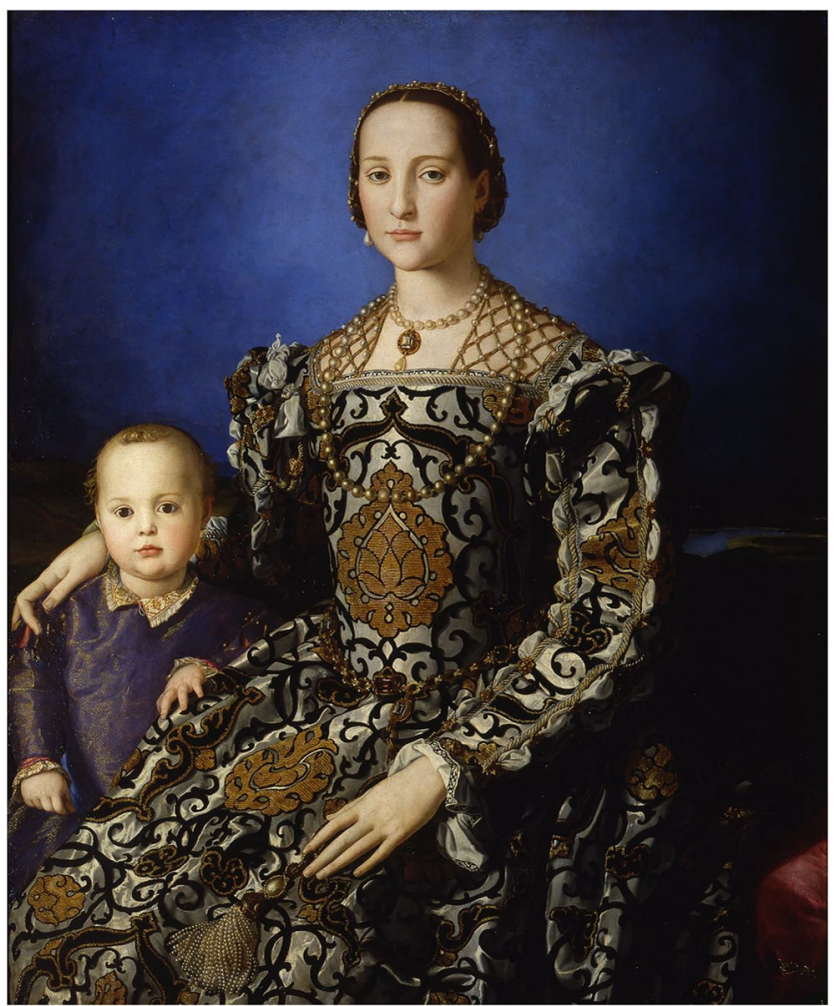

Fig. 4 Agnolo Bronzino, Portrait of Eleonora di Toledo with her son Giovanni, 1544/45, Galleria degli Uffizi, Florence (public domain) boast a long noble lineage: Cosimo I. was only the second Duke of Florence after the assassination of Alessandro de' Medici in 1537. Compared with the ancient nobility of Rome and the lords of the courts in Central and Northern Italy to which he was so eager to marry his daughters off,

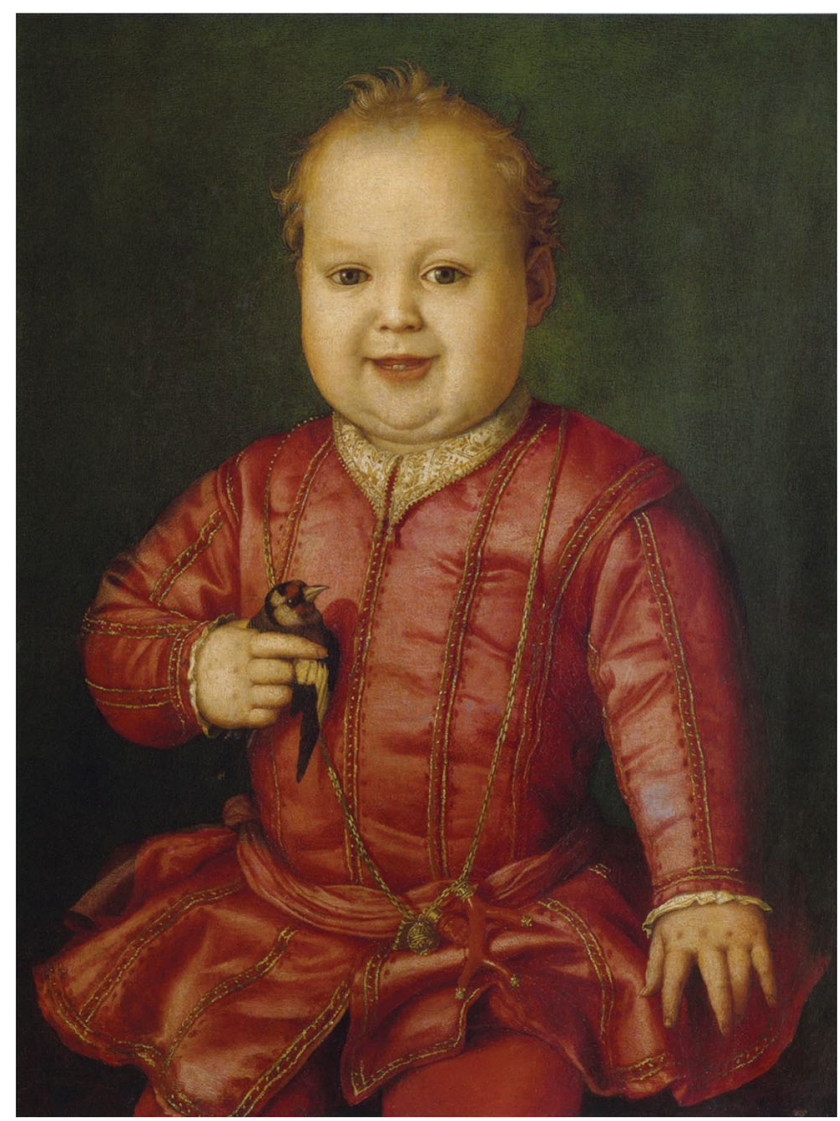

Fig. 5 Agnolo Bronzino, Giovanni de’ Medici, 1545 circa, Galleria degli Uffizi, Florence (public domain) 


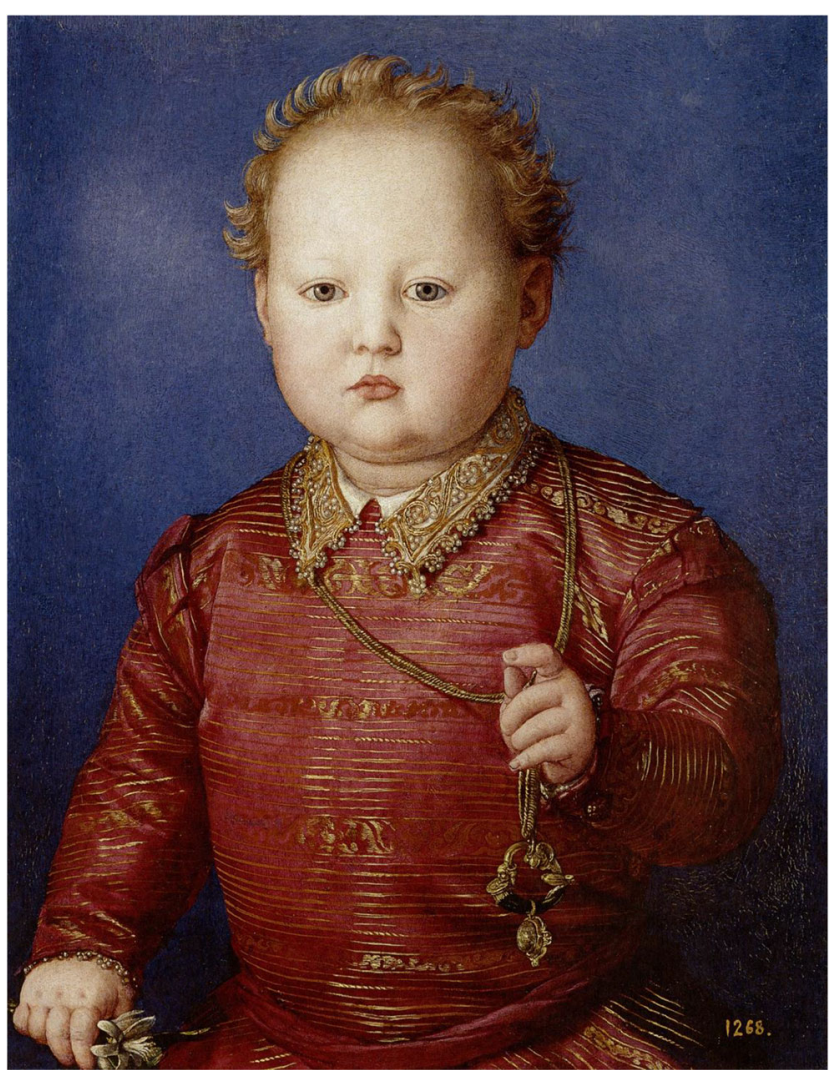

Fig. 6 Agnolo Bronzino, Don Garcia de' Medici, 1550 circa, Museo del Prado, Madrid (public domain)

Cosimo was nouveau riche, with few aristocratic credentials. His spouse and children were his capital: His Spanish wife Eleonora had produced dutifully and abundantly, and three of her sons would survive to become influential men; yet the losses of their other sons were events that were felt strongly in the close-knit family whose line had previously been in danger of extinction.

Not unlike the wealthy Roman freedmen, their offspring made up for the obvious lack of noble lineage. Hence, it does not come as a surprise that the marble bust of the little Medici boy in the Bargello is fashioned after the types of bust produced by the most famous artists for the descendants of pater patriae Cosimo de' Medici, a century earlier. Like those earlier Quattrocento bust portraits, our bust of a baby shows the horizontal lower cut which was going out of fashion in the mid-sixteenth century. It ties in perfectly with the famous bust portraits of the family's brightest stars of the Quattrocento, which adorned the rooms in the Palazzo Medici-a reminiscence of family history, a tribute to the promise of Medici children and their role in future Florentine politics, yet at the same time a statement of personal loss and the tragedy of premature death.

\section{Compliance with ethical standards}

Conflict of interest The author declares that she has no conflicts of interest.

\section{References}

1. Langedijk K (1974) Two portrait busts of a child: Filippo de' Medici by Domenico Poggini, Mitteilungen des Kunsthistorischen Institutes in Florenz XVIII, 379-383

2. Detlef H Agnolo Bronzinos Kinderbildnisse aus dem Jahre 1551, doi: https://doi.org/10.11588/mkhi.1955.2.42075 (retrieved Dec. $12,2018)$

3. Kohl J (2018) MARTIALI VERNA DULCISSIMO. Children's busts, family, and memoria in Roman antiquity and the renaissance, in: Thierry Greub and Martin Roussel (eds.), Figurationen des Porträts, Paderborn: Fink, 241-278

4. Nature doi:https://doi.org/10.1038/nature.2013.13156

5. Giuffra V, Vitiello A, Caramella D, Fornaciari A, Giustini D, Fornaciari G (2013) Rickets in a high social class of renaissance Italy: the Medici children. Int J Osteoarchaeol 25:608-624. https:// doi.org/10.1002/oa.2324

6. Fornaciari $\mathrm{G}$ et al The Medici project: first anthropological and paleopathological results. http://www.paleopatologia.it/articoli/aticolo. php?recordID=18 (retrieved Jan. 20, 2019)

7. Lapini A (1596) Diario Fiorentino di Agostino Lapini: dal 252 al 1596 , ora per la prima volta pubblicato, Firenze

8. Projetto Medici Risultate della ricercha http://www.paleopatologia.it/ attivita/pagina.php?recordID $=6$ (retrieved Jan. 20, 2019)

Publisher's note Springer Nature remains neutral with regard to jurisdictional claims in published maps and institutional affiliations. 